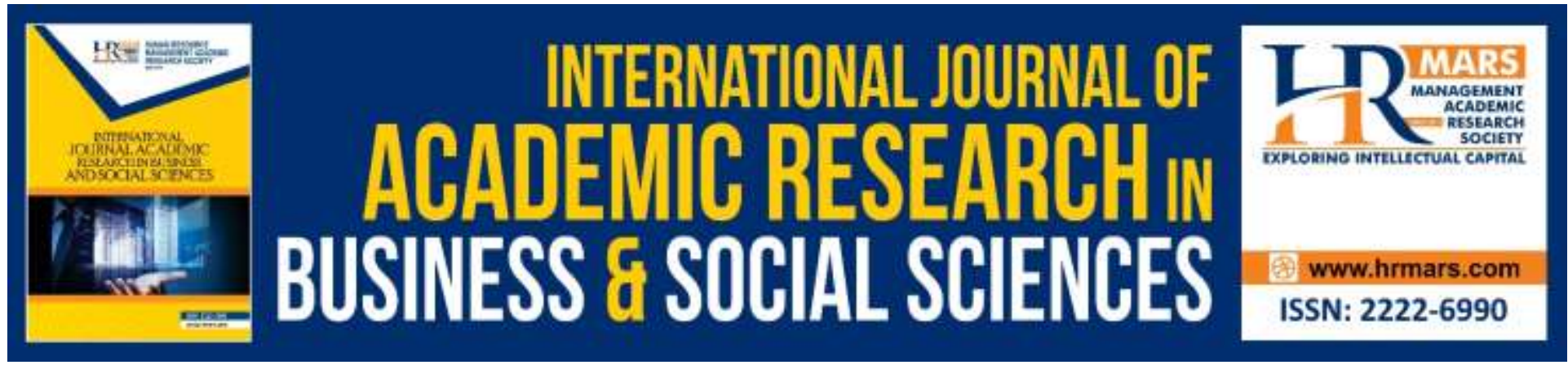

\title{
The Perception of Clients in Rehabilitation Center on Inhalant Use
}

Amin Al Haadi Bin Shafie, Mohd Khairul Anuar Rahimi, Muhammad Harith Awaludin, Nurul Ashikin Ahmat Miskam, Farhana Sabri, Noorazimah Kamaruddin, Nurhafizah Mohd Sukor, Hishamuddin Abdul Wahab, Mizan Adiliah Ahmad Ibrahim, Mohd Radhi Ibrahim

To Link this Article: http://dx.doi.org/10.6007/IJARBSS/v9-i9/6305 DOI: 10.6007/IJARBSS/v9-i9/6305

Received: 20 July 2019, Revised: 10 August 2019, Accepted: 03 September 2019

Published Online: 22 September 2019

In-Text Citation: (Shafie et al., 2019)

To Cite this Article: Shafie, A. A. H. Bin, Rahimi, M. K. A., Awaludin, M. H., Miskam, N. A. A., Sabri, F., Kamaruddin, N., ... Ibrahim, M. R. (2019). The Perception of Clients in Rehabilitation Center on Inhalant Use. International Journal of Academic Research in Business and Social Sciences, 9(9), 374-388.

Copyright: (C) 2019 The Author(s)

Published by Human Resource Management Academic Research Society (www.hrmars.com) This article is published under the Creative Commons Attribution (CC BY 4.0) license. Anyone may reproduce, distribute, translate and create derivative works of this article (for both commercial and non-commercial purposes), subject to full attribution to the original publication and authors. The full terms of this license may be seen

at: http://creativecommons.org/licences/by/4.0/legalcode

Vol. 9, No. 9, 2019, Pg. 374 - 388

http://hrmars.com/index.php/pages/detail/IJARBSS

JOURNAL HOMEPAGE

Full Terms \& Conditions of access and use can be found at http://hrmars.com/index.php/pages/detail/publication-ethics 


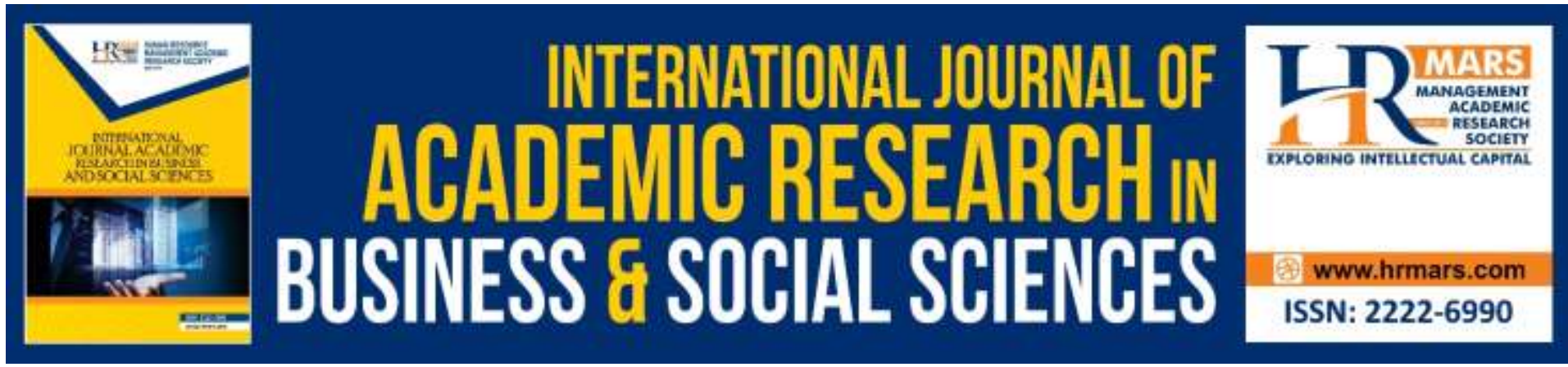

\title{
The Perception of Clients in Rehabilitation Center on Inhalant Use
}

Amin Al Haadi Bin Shafie ${ }^{1,2,5}$, Mohd Khairul Anuar Rahimi ${ }^{1,2}$, Muhammad Harith Awaludin ${ }^{1,5}$, Nurul Ashikin Ahmat Miskam ${ }^{1,5}$, Farhana Sabri ${ }^{1,2,5}$, Noorazimah Kamaruddin ${ }^{4}$, Nurhafizah Mohd Sukor ${ }^{1,2}$, Hishamuddin Abdul Wahab ${ }^{3}$, Mizan Adiliah Ahmad Ibrahim $^{1,2,5}$, Mohd Radhi Ibrahim ${ }^{2}$

${ }^{1}$ Asian Center for Research on Drug Abuse (ACREDA), Universiti Sains Islam Malaysia (USIM), ${ }^{2}$ Fakulti Kepimpinan dan Pengurusan (FKP), Universiti Sains Islam Malaysia (USIM), ${ }^{3}$ Fakulti Sains dan Teknologi (FST), Universiti Sains Islam Malaysia (USIM), ${ }^{4}$ Agensi Anti Dadah Kebangsaan (AADK), Kementerian Dalam Negeri (KDN)

${ }^{5}$ Institute Sains Islam (ISI), Universiti Sains Islam Malaysia (USIM)

\begin{abstract}
This study identifies the clients' perception regarding to the inhalant use, consumption period, types of inhalant, inhalant as gateway substance and whether inhalant is not a choice or still being used. This study has adopted quantitative and qualitative approach. Samples of study were clients from selected rehabilitation centers including CCRC Dengkil, CCRC Jelebu, CCVC Sepang, C\&C Tampin, CCRC Serendah, CCRC Kg. Selamat, C\&C Bukit Mertajam, CCRC Muar, CCRC Papar dan CCRC Sarawak. The centers selected constituted to $10 \%$ of rehabilitation centers available in Malaysia. Total of respondents for quantitative were $n=263$ and for face-to-face interview, 10 participant were selected to triangulate the data from questionnaire. The samples were selected by using purposive sampling technique. The data from questionnaire was analyzed by using descriptive statistic to generate the data acquired. The transcribed interviews were analyzed and governed by using content analysis technique. Result showed that, inhalant use among clients in rehabilitation center is still progressively occurred. Most of them use inhalant for less than 5 months and the most popular and favored type of inhalant is glue or specifically called as "gam cap senapang". A new innovated of inhalant is produced in which the combination of substances are made to fulfil the sense of pleasure. This study shows the classic theory of 'gateway' is agreeable.
\end{abstract}

Keyword: Perception, Teacher, Inhalant, ACREDA, Drug 


\section{Introduction}

The menace of inhalant use is still happening in rehabilitation center. Sometimes, clients in rehab center failed to control their relapse and intensely need to fulfil the withdrawals by taking inhalant as substitute to drug. At the age of early adolescent, an individual that is exposed to the risk factors of substance abuse is prone to take inhalant and will stop consuming after some years. The inhalant use among adolescents is associated with previous experience at school like school evacuation (Howard, Bowen, Garland, Perron \& Vaughn, 2011). National Institute on Drug Abuse (NIDA) in 2012, stated that adolescents in the range of age from 12 to 17 years old is the peak phase of taking inhalant notably at the age of 14 . Haslina, Abdul, Elena, \& Chindan Regin (2008), in Malaysia, the term of inhalant use always been called as 'glue sniffing'. Adolescents are easily accessing to the inhalant substances such as aerosol spray, adhesive, bleach, floor liquid and other chemical products which are accessible in supermarket and other stores. The clients in rehabilitation CENTER are also sneakily using inhalant during vocational activities and this activity needs major attention from responsible parties.

Thus, this paper will discuss the clients' perception on the use of inhalant among client in rehabilitation CENTER. Researchers also were accessing the consumption period of inhalant use among clients based on their experience and the types of inhalant they used before taking drugs or other substances. In addition, this study examine the emerging data acquired from clients who produce innovated inhalant to heighten the pleasurable and the perception of user about inhalant as gateway. The reasons why inhalant is replaced with other drugs among client in rehabilitation CENTER also will be discussed in this paper.

\section{Literature Review}

The transition phase of childhood onto adult age is called adolescence phase. This phase is characterized the reformation of physical, psychological, emotional and social also, the development of internal and external physical. Adjustment of an adolescent happened in social structure, and emphasize on held with friends group. Plus, adolescents are assimilating other's behavior, physical appearance, verbal instruction, habits and affect their health (Zagury, 2001).

One of the biggest issues in Mexico regarding public health is drug abuse. Adolescents that involve in National Addictions Research resulting with more than 200,000 adolescents between 12 and 17 years old involved in drug abuse. Based on gender, every female user is ratio with 3.5 male users and the initiating age of consumption is 14 years old. Statistic show the prevalence of drug abuse is mostly in the population of adolescent and this becomes one of the most problematic temperaments.

World Health Organization defined adolescent as individuals between the ages of 10 and 19. Adolescents are the phase of change between the final phase of childhood and the early phase of adolescence, and mark the beginning of the human reproductive lifespan (Choudhury, Blakemore, and Charman, 2006).

According to Hollen (2009) in Rozmi, Azri, Fauziah and Salina (2017), he defined inhalant abuse as an act that violates the proper use of the procedure or uses a prohibited substance such as narcotics, drugs, substances contained in alcohol or any substance or by the way that can put others in a dangerous state. Substance abuse in street children around the world is between $50 \%$ and $80 \%$ (Tiwari, 2006) and inhalant becomes one of the most commonly used drugs besides alcohol and tobacco (Njord, Merril, Njord, Lindsay, \& Pachano, 
2010). Substance abuse is closely related to adolescents, especially among adolescents with potentially risk. The problem of behavior and mental health is because of inhalant use in which this issue becomes a concern because it involves universal health (World Health Organization 2016; Wolfe \& Mash 2006; Ismail, Ghazali \& Ibrahim 2015).

According to the Substance Abuse and Mental Health Services Administration (SAMSHA) in Adam (2006) reported on March 16, called "Characteristics of Recent Adolescent Inhalant Initiates", the most popular substance amongst consumers are, glue, shoe polish or toluene $(30.3 \%)$; nitrous oxide (24.9\%); painting spray $(23.4 \%)$; floor cleaning liquid or correction liquid (18.4\%); aerosol spray (18\%); amyl nitrite, wardrobe fragrance (14.7\%); and thinner or solvent (11.7\%). Based on National Institute of Drug Abuse (NIDA), inhalant refers to a group of psychoactive substances that change into vapour and results in brain functions changes. Brouette and Anton (2001) defined inhalant as a volatile substance at room temperature, not categorized into any drug category such as nicotine and cocaine, and is used in many ways such as sniffing, snorting and bagging.

Among the commonly used inhalant are petrol, paint, thinner, paint remover, glue, pen, adhesive and bleach (Verma, Balhara \& Deshpande, 2011). The use of inhalant is one of the most harmful substances that can cause serious injuries and death (Pfeiffer, Al Khaddam, Brinkmann, Kohler, \& Beike, 2006; Chakroun, Faidi, Hedhii, Charbaji, Nouaigui, \& Laiba, 2008) neurobiological effects (Yucel, Lubman, Solowij, \& Brewer, 2007). Inhalant will activate the brain dopaminergic system and cause euphoric effect (O'Leary-Moore, Galloway, McMechan, Irtenkauf, Hannigan \& Bowen, 2009). Inhalant is able to excite the emotion into an extreme excitement or euphoria, high, dizziness, retarded and anxiety. With chronic abuse, inhalant can cause neurological damage, kidney failure, haematological and intoxication (Atay, 2005). Verma, Balhara and Deshpande (2011) in a study shows inhalant is a hazardous substances that can cause serious damage or death. Study conducted in hospitals for collecting the data of clients and being accessed. The finding shows the age of initiating the use of inhalant is at age 14 years old and the main factors are from experimentation (94\%) and peer influence (97\%).

One long term study by Amanda \& Bethany (2016) to investigate the trend of inhalant use among adolescent and demographic of inhalant users also identify the beginning of using inhalant. The finding of study shows that the trend is decline at certain period of time.

From the samples, $69 \%$ used inhalant as the first psychoactive substance and $42 \%$ reported only using inhalant. In addition, $67 \%$ were reported to be the preferred psychoactive substance, $28 \%$ making it the second choice. This study also examines the most commonly used inhalant in which $29 \%$ use correction pen, $26 \%$ are reported using solvents. Other ingredients include glue, adhesive, and thinner which recorded $11 \%$, petrol and grease recorded $3 \%$.

Numerous studies found adolescents at age of 12-16 years old were a significant development phase and have tendency to abuse substance (Flight, 2007). Adolescents who are in that range of age tend to abuse substance including alcohol, tobacco, marijuana and drugs for the first attempt (Krank, Stewart, O'Connor, Woicik, Wall, \& Conrod, 2011). Adolescents who have been exposed to substance abuse from young age have the potential to abuse substance during adult (Rozmi et al., 2017).

Various factors contributed to negative misconduct. Based on existing theories, adolescents tend to be delinquent if they are often exposed to risk factors (Turner, Powell, Langhinrichen, Rohling \& Carson, 2009). Behavioral problems often occur in risky social 
environments and school environments that relate to other factors creating behavioral problems and influencing devian behavior (Farral \& Flannery, 2005). Children who grow up in a risky environment will be exposed to a range of criminal activities such as drug trafficking, witnessing drug abusive such as drug injections and eventually getting used to the situation and related equipment (Mayes \& Suchman, 2006).

Adolescent experts believe that peer influence is a core to adolescent, something that adolescents need to learn to manage the social life when they grow up (Brown, Bakken, Ameringer, \& Mahon, 2008). There are numerous studies found that adolescent see their peers more like themselves in the use of alcohol, cigarettes, illicit drugs and sexual behavior (Pristein \& Wang, 2005). Among other studies (Beauvais et al., 2002) on three groups, namely American Indian, Mexican America and non-Latino White shows that perceptions and social factors affecting these three groups to take inhalant. Plus, the influence of friends also shows among the strongest triggers in inhalant taking (Oetting \& Beauvias, 1988).

The use of inhalant is often associated with misconduct, depression and suicide (Borges, Walters, \& Kessler, 2000; Kelder, Murray, Orpinas, Prokhorov, McReynolds \& Zhang, 2001). According to Oman et al. 2004, being homelessness or has no permanent place with family contributed to the increase in inhalant misuse among adolescents. The suppressed environment increases risks in drug and psychosocial abuse (Wolfe \& Mash, 2006).

Moreover, according to Wittig, Wright \& Daminsky (1997), the findings of the study have shown similarities with the reports where the habit of the user is from adolescent. They are from adolescent who drop out of school and from low income families (Seth, Kotwal, \& Ganguly, 2005). The behaviour substance abuse from parents is closely related to the behavior of their children (Verma, Balhara \& Deshpande, 2011).

Rozmi et al. (2017) found that social environment factors were factors that contributed to substance abuse among adolescents. The results of this study have been supported by other studies of Turner et al. (2009) and Rosser, Stevens and Ruiz (2005) which stated that school factors are an important medium in developing adolescent's behavior. This study also found that the behavioral abuse of substance occurs when environmentally risky factors such as accessible substance. Plus, factors of peers that introducing prohibited substances and factors of lack of knowledge about drugs also contribute to substance abuse without knowing their side effects.

\section{Methodology}

Research Design

This study has adopted survey and narrative design. The study use questionnaire for survey design and the data is triangulated with qualitative data to enrich the information obtained from the questionnaire. Researcher seek to describe trends in a large population of individuals and administer a questionnaire to a small group of people or sample to identify trends in attitudes, opinions, behaviors, or characteristics (Creswell, 2012). Qualitative research methods would be useful in cases where the researcher wishes to gather a general idea from the subjects, the goal being to explore, interpret and describe a situation. There are several methods of data collection in qualitative methods such as interviews, observations, collecting documents and data from the audio-visual such as pictures, video recording, film and art objects and else (Creswell, 2003). In this study, interview method was chosen as researcher intent to obtain information and feedbacks from the participants. 
Sample

Samples of this study are clients from selected rehabilitation CENTERs include CCRC Dengkil, CCRC Jelebu, CCVC Sepang, C\&C Tampin, CCRC Serendah, CCRC Kg. Selamat, C\&C Bukit Mertajam, CCRC Muar, CCRC Papar dan CCRC Sarawak. Samples consist of clients with inhalant use history and aged between 20 to 40 years old. The CENTERs comprised $10 \%$ of rehabilitation CENTERs available in Malaysia. Total of respondents for survey are $n=263$ and for face-to-face interview, 10 respondents was selected to triangulate the data from questionnaire. The samples are selected by using purposive sampling technique. The purposive sampling technique, also called judgment sampling, is the deliberate choice of a participant due to the qualities the participant possesses. It is a non-random technique that does not need underlying theories or a set number of participants. Simply put, the researcher decides what needs to be known and sets out to find people who can and are willing to provide the information by virtue of knowledge or experience (Bernard, 2002).

Data collection

The questions for survey are developed by researchers. The content of questionnaire is verified using face validity by two experts in statistic and psychology field. This study used self-developed questionnaire and had undergone pilot test to testify the reliability. The value of Cronbach's Alpha is 0.51 . However, the reliability test is not important for this study because no correlation identified by researchers. The questionnaire consists of three sections which are Section (A): Client demographic, Section (B): the information of inhalant use and Section (C): the views of client on inhalant use. The questionnaires were distributed to the clients at selected rehabilitation CENTERs by researchers. Moreover, semi-structured questions were developed by researchers for guideline during interview. The protocol question had been verified by experts from statistic and psychology field. Two clients from each CENTER were chosen for qualitative data. This study administered face-to-face interview with clients in rehabilitation CENTER to triangulate the data from questionnaire.

\section{Data Analysis}

The data from questionnaire is analyzed using descriptive statistic to generate the data. The data is presented in percentage and frequency. Data from the survey is triangulated with data from interviews. The quantitative data is analyzed by using content analysis. The content analysis conducted is simple and brief. The process of categorizing the themes is based on questionnaire from survey for triangulation of data. According to Powers and Knapp (2006), content analysis is a strategic coding by categorizing the large amount of textual information based on the patterns and trends of words and discourse of communication into answering research questions. Content analysis works by examining the narrative materials attained analytically and breaking the texts into respective contents and submitting them to descriptive treatment (Sparker, 2005).

\section{Results}

The finding from this study shows that the prevalence of inhalant use among client in rehabilitation CENTER is still becoming one of the issues that acquire less concern from responsible parties. Among the clients, the consumption of inhalant is temporary and in short period of intake. Most of them consumed inhalant for less than one year and deliberately change to drugs. From the data retrieved, glue is the most favoured type of inhalant among 
clients and the most popular brand is "gam cap senapang". The inhalant use among clients is not referred and limited to certain types of inhalant substance; it is modified and innovated by clients to produce a new inhalant substance for the sake of intense pleasure. Furthermore, researchers determine the perception of client regarding the inhalant as gateway substance to another drug. Clients undoubtedly conceded the inhalant as gateway substance and most of them have history report on inhalant use. The data from interviews exhibits the inhalant is not a prior choice among client due to the intention to change the behaviour or switch to drug.

The prevalence of inhalant use among clients

Result from questionnaire shows clients in rehabilitation CENTER have stopped from taking inhalant. $92 \%$ of clients responded for not taking inhalant and $21 \%$ still using inhalant even in rehabilitation CENTER.

Table 1: The percentage of inhalant use among clients in rehabilitation CENTER: $\mathbf{N}=\mathbf{2 6 3}$

\begin{tabular}{|c|c|c|c|c|c|}
\hline & & $\begin{array}{c}\text { Frequenc } \\
y\end{array}$ & Percent & $\begin{array}{c}\text { Valid } \\
\text { Percent }\end{array}$ & $\begin{array}{l}\text { Cumulative } \\
\text { Percent }\end{array}$ \\
\hline \multirow[t]{3}{*}{ Valid } & Yes & 21 & 8.0 & 8.0 & 8.0 \\
\hline & No & 242 & 92.0 & 92.0 & 100.0 \\
\hline & Total & 263 & 100.0 & 100.0 & \\
\hline
\end{tabular}

Clients in rehabilitation CENTER show the significant existence of the use of inhalant in the CENTER itself. The respondents interviewed had history of using inhalant. From the interview conducted, the use of inhalant still happened even in rehabilitation CENTER. According to the respondents in the CENTER, they used inhalant occasionally and sneakily brought the inhalant during vocational activity. Some of the clients claimed that they will keep the inhalant substance smug from vocational activities. This shows the use of inhalant still occurred even in rehabilitation CENTER.

"We plan with our friends to bring the inhalant especially glue during vocational activity sneakily. During weekend, we gathered and enjoy?" (Respondent 6)

Most of the clients in rehabilitation CENTER have stopped from taking inhalant since they were admitted in the CENTER.

"...3 months before I enter this CENTER, is still take inhalant. When I am here, I didn't take it" (Respondent 7)

"Before I enter this CENTER, I still use it. Now, I've been here about one month and one week. Now I'm not taking the inhalant anymore" (Respondent 3)

It can be concluded that, the inhalant use is still progressing in rehabilitation CENTER among client even majority of client had stopped since they admitted into the CENTER.

The period of consumption of inhalant

The table shows $64.3 \%$ of the clients in rehabilitation CENTER had consumed inhalant for less than one year and a few of them (35.7\%) use it can be concluded that inhalant is one of the substance that unsustainable and only be used in short period of time. 
Table 2: The period of inhalant consumption: $\mathbf{N}=\mathbf{2 6 3}$

\begin{tabular}{|ll|r|r|r|r|}
\hline & Frequency & Percent & Valid Percent & $\begin{array}{c}\text { Cumulative } \\
\text { Percent }\end{array}$ \\
\hline Valid 5 months and below & 114 & 43.3 & 43.3 & 43.3 \\
& 5 months until a year & 55 & 20.9 & 20.9 & 64.3 \\
More than a year until & 94 & 35.7 & 35.7 & 100.0 \\
now & 263 & 100.0 & 100.0 & \\
Total & &
\end{tabular}

The finding from interview shows most of the users or former users use inhalant within less than 6 months and occasionally. The replacement of substance (inhalant to other drugs) drives from several factors such as need of satisfaction.

"If I am not mistaken, I started using inhalant since form 3 within 6 months but occasionally and gradually stop from taking inhalant." (Respondent 7)

It can be concluded that, most of the inhalant user used inhalant in a very short of time. Majority of them sustained with inhalant for only less than one year.

Type of inhalant used

Table below depicts the types of inhalant used by clients. Based on survey data, glue recorded the highest percentage (71.9\%) which the most frequent type used by clients.

Table 3: Percentage of type of inhalant used: $\mathbf{N}=\mathbf{2 6 3}$

\begin{tabular}{|c|c|c|c|c|c|}
\hline & & $\begin{array}{c}\text { Frequenc } \\
y\end{array}$ & Percent & $\begin{array}{c}\text { Valid } \\
\text { Percent }\end{array}$ & $\begin{array}{c}\text { Cumulative } \\
\text { Percent }\end{array}$ \\
\hline \multirow[t]{6}{*}{ Valid } & Glue & 189 & 71.9 & 71.9 & 71.9 \\
\hline & Petrol & 8 & 3.0 & 3.0 & 74.9 \\
\hline & Others & 11 & 4.2 & 4.2 & 79.1 \\
\hline & All types of inhalant & 8 & 3.0 & 3.0 & 82.1 \\
\hline & More than one type & 47 & 17.9 & 17.9 & 100.0 \\
\hline & Total & 263 & 100.0 & 100.0 & \\
\hline
\end{tabular}

Based on interview conducted with clients in rehabilitation CENTER, type of inhalant use is glue. Some of them stated that they mix the substance to produce a new inhalant product. Most of them mentioned "cap senapang" glue that always the best choice of inhalant. Clients disclose the type of inhalant used include petrol and thinner.

"glue and petrol" (Respondent 1)

"I used thinner and sometimes glue. But I used petrol the most. I need to mix it.

Petrol is too pungent if it is used by itself. We combined with polystyrene and after that put it under air conditioner. It will turn glue-like substance." (Respondent 6)

"I used bicycle tube adhesive. Cap senapang." (Respondent 5)

Hence, the fact that inhalant is closely related with glue is undeniable. This study clearly approved that glue is the most favoured types of inhalant among clients in rehabilitation CENTER and "gam cap senapang" is the famous brand among users. 
Inhalant as a 'gateway'

The data from questionnaire proves that inhalant is a 'gateway' substance to other drug. Clients agreed inhalant is a 'gateway' and prone to take other drugs. High percentage of clients $(67.7 \%)$ agreed while $31.9 \%$ disagreed that inhalant is 'gateway' to other substances.

Table 4: Inhalant as a 'gateway' substance: $\mathrm{N}=\mathbf{2 6 3}$

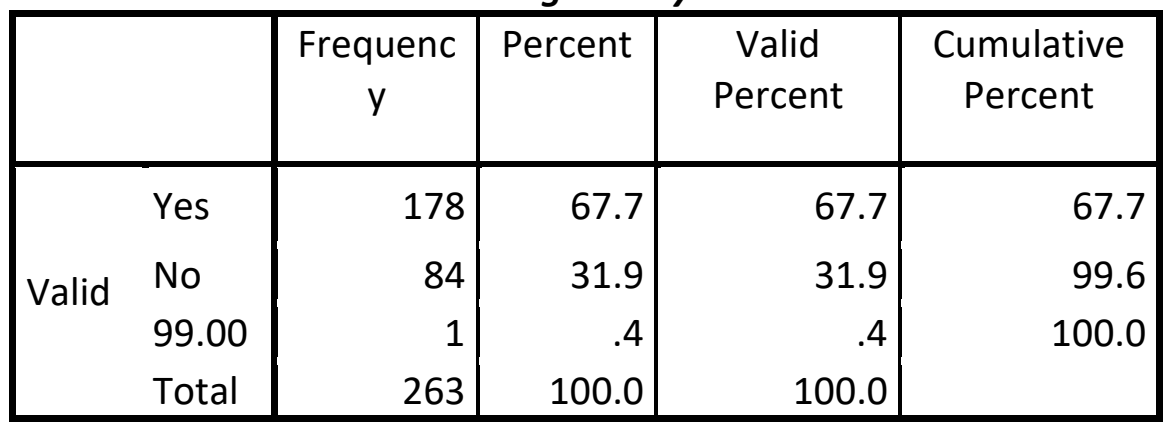

The data from questionnaire is supported by data from interviews. Most of the interviewed clients agreed inhalant as a 'gateway' to other substance. Several clients disagreed because for them, inhalant is an alternative substance.

"I agree because it happened to myself." (Respondent 1)

"Agree. I started with sniffing the glue, after that I want to try other things." (Respondent 3)

Therefore, the study shows inhalant is considered as a 'gateway' substance as it is mentioned by the former inhalant user reported in survey data and face-to-face interviews.

Inhalant is not a choice

Clients in rehabilitation CENTER had gone through a journey of substance abuse since taking mild substance such as inhalant until drugs. Inhalant is typical substance that remains in short time and users will choose other substances to fulfil the pleasure. Inhalant is stoppable because users intent to stop taking inhalant as self-awareness arises, change from inhalant to drugs, and seek for stronger substance devoted to highest level of excitement.

"I feel so jealous with my ex-wife because she has a new husband. I want to prove to her that I am a man too and same with others" (RP6)

"I wanted to try a new thing..." (RP4)

"I change from using inhalant to drug because inhalant is so boring. Can you imagine taking the same thing every day. Boring! If you have money, you won't maintain with inhalant and you will find and want to try other drugs" (R5)

This data retrieved from interviews conducted with clients. Some clients stop from using inhalant is because they are trying to change their behaviour to be a better person. Other than that, several of them are no longer taking inhalant because they want to use other substance like drugs.

\section{Discussion}

This research has identified the inhalant use among adolescents. The qualitative research was conducted to access the perception of clients in rehabilitation CENTER regarding to inhalant use. Clients in rehabilitation CENTER have the history line of substance use since the first substance they consumed. Clients selected as research's participants were those who 
committed with inhalant use even for temporary use or in long period of consumption. Researchers were able to access the use of inhalant among clients in rehabilitation CENTER, the initiating age of inhalant use, the period of inhalant use, the type of inhalant used, other substances used with inhalant, factors of inhalant taking, the perception of inhalant as gateway, and the reasons inhalant is no longer a main choice among users.

\section{The Prevalence of Inhalant Use among Clients}

This study examines the history of clients when they were using inhalant previously. Data are obtained from questionnaire and face-to-face interviews with clients in rehabilitation CENTER. From the finding, only a few clients still using inhalant even in rehabilitation CENTER and most of them are not taking any substances since they were admitted in the CENTER. Clients that still consume inhalant in rehabilitation CENTER obtained the inhalant from vocational activities. They brought the substances that purposely for carpentry, and then consume it in group during weekend. Some of them take inhalant for the sake of pleasure. According to Hazman et. al (n.d), studies related to the phenomenon of glue sniffing have never been made in Malaysia. However, this phenomenon seems to be serious in some places around Malaysia although this symptom is not very apparent as the main focus of the study because the study is more focusing on the issue of drug.

The Period of consumption of Inhalant

This study shows inhalant use is temporarily where $43.3 \%$ use inhalant for less than 5 months. This is because they found and tried other substances that bring more pleasure compared to impact of taking inhalant. Based on clients' experience, inhalant triggers a least effect of pleasure compared to other substances. The finding revealed most of the clients use inhalant for less than 5 months (43.3\%) and 35.7\% involved in inhalant use for more than 1 year. In a study of inhalant in Hydraabad, India among street children that use 'whitener' as inhalant. This study identifies the period of using inhalant and the average of period in inhalant use among street children is 2 years. The duration of inhalant use shows street children using inhalant in long term period. The factors contributing include poverty and low economic status. Both factors are insisting the children to use inhalant substance in a very long time. Study in Hydraabad depicts the street children use inhalant continuously without consuming other drugs. However, the study in Hydraabad contradicts with result obtained in this research, where in Malaysia, the duration of inhalant use is less than one year. According to respondent, when they started to work and have extra money, they will use drug. Most of the respondents change to another substance for the sake of pleasure.

\section{The Types of Inhalant Used}

From the findings, the most favoured inhalant types among clients were glue. The data from questionnaire shows $71.9 \%$ from all respondents use glue as inhalant. This data is specified with data from face-to-face interview where the brand of glue that frequently the top choice among users is gam cap senapang. The findings similar with one study by Verma et. al (2011), among the commonly used of inhalant are glue, petrol, paint, thinner, paint remover, correction pen, adhesive and bleach. There are numerous studies that find glue is a type of inhalant that often being used among adolescents. Based on Substance Abuse and Mental Health Services Administration (SAMSHA) in Adam (2006), the most popular substance among drug users are glue, followed by shoe polish or toluene, nitrous oxide, 
painting spray, cleaning liquid floor cleaning or correction fluid, aerosol spray, amyl nitrite, wardrobe fragrance, and thinner or solvent.

Inhalant as a 'Gateway' Substance

This study show majority of clients agree that inhalant is a 'gateway' to another type of drug. $67.7 \%$ agree that inhalant substance is a 'gateway' substance to other drug abuse while $31.9 \%$ disagree that inhalant is 'gateway' to other drugs. Inhalant is a substance that will trigger the user to consume other types of drugs that bring more satisfaction. Normally, they start with cheaper and convenience substances and believe that this substance does not have severe effect despite the effects experienced such as headaches, high and addiction. Shamblen and Miller (2012) shows the use of inhalant usually will trigger the use of a variety of other substances and will cause harmful side effects. Despite the fact that inhalant is the main focus of this study, adolescent using inhalant substance tend to use different substance than adolescent who begin with marijuana or alcohol. The findings of Shamblen and Miller (2012) find that teenagers who start with alcohol or marijuana will remain with alcohol and marijuana. The tendency for teenagers to switch from alcohol after starting with inhalant is less and they prefer to use a stronger drug.

Therefore, it is clear that the inhalant is a gateway to other drugs. The inhalant is used as an 'initiator' before taking drugs as it is accessible, and low cost. Most of the parties are focusing on drug issues that are widespread in Malaysia. The inhalant issue is not the main focus because it is not perceived as a serious issue. However, historical records of the use of inhalant can be obtained if drug addicts are detained in rehabilitation CENTERs. Nevertheless, the post-effects of the inhalant use have long term impact. Thus, before it comes to the worst, prevention is more important than cure.

Inhalant is not a Choice

The clients view inhalant as an alternative to avoid from relapse. The clients that had have undergone the treatment in rehabilitation CENTER and eligible to come out from the CENTER will experience the triggers when they meet their friends, and the place they use drug and eventually relapse. Thus, to avoid from retaking the drugs, they use inhalant as an alternative to fulfil the pleasure. They also use inhalant as to cope the stressful situation and reduce the depression due to external factors include environment and family. The intention to change the behavior from taking inhalant that can be destructive is one of the factors why clients in rehabilitation CENTER stop from taking inhalant. However, even they stop from taking inhalant; they are consuming other substances such as drugs to seek pleasure.

\section{Conclusion}

In conclusion, inhalant use among clients in rehabilitation CENTER was still occurred. Based on history of clients, most of them used inhalant for less than one year and the most popular and favoured type of inhalants is glue or specifically called 'cap senapang'. Client's also innovate a new product of inhalant where combination of substances are made to fulfil the gratification. Verifying the classic theory of 'gateway', most of the clients agreed that the inhalants use at early addiction activity is prone to use other substances or drugs. Plus, inhalant is an alternative among clients in rehabilitation CENTER when drug is absent and to reduce the relapse rate from retaking drugs. Self-awareness and intention to change is the factors of avoiding choosing inhalants and other substances. 
This research can be used for future study in order to investigate the correlation between clients in rehabilitation CENTER and other aspects for instance the 'gateway' rate, the relapse rate and factors contributing. This research had contributed in term of collecting the profile of client, thus can be accessed for upcoming research. The methodological part can be more in depth analysis for any researchers that wish to further the research in wider scope.

\section{Acknowledgement}

It is to acknowledge that this paper is fully funded by National Anti-Drug Agency (NADA) in collaboration with researchers from Asian CENTER for Research on Drug Abuse, Universiti Sains Islam Malaysia.

\section{Reference}

Adam, J. Cox. (2006). Treating Inhalant Abuse by Prevention and Raising Parental Awareness. Wiley Interscience, 22(55).

Arnett, J. J. (2007a). Emerging adulthood: What is it, and what is it good for? Child Development Perspectives, 1, 68-73.

Berndt, T. J. (1996). Transition in friendship and friends' influence. In J. A. Graber, J. BrooksGunn, \& A. C. Petersen (Eds.). Transitions through adolescence: Interpersonal domains and context, pp. 57-84.

Bernard, H. R. (2002). Research methods in anthropology: Qualitative and quantitative approaches (3rd ed.). Walnut Creek, CA: Alta Mira Press.

Borges, G., Walters, E. E., \& Kessler, R. C. (2000). Associations of Substance Use, Abuse, and Dependence with Subsequent Suicidal Behavior. Am J Epidemiol,151:781-9.

Brouette, T., \& Anton, R. (2001). Clinical review of inhalants. American Journal on Addictions, 10, 79-94.

Brown, J. P., Ameringer, S. W., \& Mahon, S. D. (2008). A Comprehensive Conceptualization of Peer Influence Process in Adolescence. In Jeffrey J. Arnett (2010), Adolescence and Emerging Adulthood. United States. Pearson Education, 219-221.

Beauvais, F., Wayman, J. C., Jumper-Thurman, P., Plested, B., \& Helm, H. (2002). Inhalant Abuse Among American Indian, Mexican American, and non-Latino White Adolescents. American Journal of Drug and Alcohol Abuse, 28(1), 171-187.

Choudhury, S., Blakemore, S.-J., \& Charman, T. (2006). Social cognitive development during adolescence. Social Cognitive \& Affective Neuroscience, 1(3), 165-174.

Farrel, A. D. \& Flannery, D. J. (2005). Youth violent prevention are we there yet? Aggresion and Violent Behavior, 11: 138-150.

Flight, J. (2007). Canadian addiction survey: A national survey of Canadians' use of alcohol and other drugs: Substance use by youth. Ottawa: Health Canada.

Hall, G. S. (1904). Adolescence: Its psychology and its relation to physiology, anthropology, sociology, sex, crime, religion, and education. Englewood Cliffs, NJ: Prentice-Hall.

Hazman, S., Che Bakar, C. M., Wan Hamdi, N. (n.d). Fenomena penyalahgunaan dadah dan hidu gam serta kesannya kepada sistem nilai. Universiti Teknologi Mara, Cawangan Sarawak, Kampus Samarahan.

Hollen, K. H. (2009). Encyclopedia of Addiction. West Port, CT: Greenwood Publishing Group. 
Ismail, R., Ghazalli, M.N \& Ibrahim. N. (2015). Not all developmental assets can predict negative mental health outcomes of dsadvantaged youth: A case of suburban Kuala Lumpur. Mediterranean Journal of Social Sciences, 6(5): 452-461.

Johnson L. D., O'Malley P. M., \& Bachman J. G. (2007). Schulenberg J.E.Monitoring the Future: Krank, M., Stewart, S. H., O'Connor, R., Woicik, P. B., Wall, A. M., \& Conrod, P. J. (2011). Structural, concurrent, and predictive validity of the substance use risk profile scale in early adolescence. Addictive Behaviors, 36 (1- 2): 37-46.

Kerner, K. (1988). Current topics in inhalant abuse. In : Crider, R., and Rouse, B., eds. Epidemiology of Inhalant Abuse : An Update. Research Monograph 85.Rockville, MD : National Institute on Drug Abuse.

Mahmood, N. M. (2008). Perubahan dalam senario rawatan dan pemulihan penagihan dadah: Cabaran dalam pengurusan pemulihan dadah di malaysia dan arah masa depan. Universiti Utara Malaysia: Sintok.

Mayes, L. C. \& Suchman, N. E. (2006). Developmental pathways to substance abuse. In Developmental Psychopathology, New York: John Wiley and Sons.

National Survey Results on Drug Use. (2006). National Institute on Drug Abuse. Bethesda, MD. Navaratnam, R. (1988). The problem of Inhalant abuse in the South -East Asian / Western Pacific Region: A regional analysis. In Arif, A.; Grant, M.; and Navaratnam, V., eds. Abuse of Volatile solvents and Inhalants: Papers Presented at a W.H.O. Advisory Meeting. Penang, Malaysia: W.H.O. Training Center, Universiti Sains Malaysia, pp 16-23.

NIDA (National Institute on Drug Abuse). (2010). Inhalant abuse: Research report series. NIH Publication Number 10-3818. Washington, DC: NIDA, National Institutes of Health, U.S. Department of Health and Human Services. Retrieved September 3, 2010.

Njord, L., Merril, M. R., Njord, R., Lindsay, R., \& Pachano, R. D. J. (2010). Drug use among street children and non-street children in the Philippines. Asia Pacific Journal of Public Health, 22, 203.

O'Leary-Moore, S. K., Galloway, M. P., McMechan, A. P., Irtenkauf, S., Hannigan, J. H., \& Bowen, S. E. (2009). Neurochemical changes after acute binge toluene inhalation in adolescent and adult rats: A high resolution magnetic resonance spectroscopy study. Neurotoxicology and Teratology, 31, 382-389.

Oetting, E. R., \& Beauvias, F. (1988). Common elements in youth drug abuse: peer cluster and other psychosocial factors. In Visions of Addiction; Peels, S., Ed.; D.C. Health and Company: Lexington; 141-161.

Patton, M. Q. (2002). Qualitative research and evaluation methods. 3rd ed. Thousand Oaks, CA: Sage.

Pfeiffer, H., Al Khaddam, M., Brinkmann, B., Köhler, H., \& Beike, J. (2006). Sudden Death After Isobutane Sniffing: A Report of Two Forensic Cases. Int J Legal Med, 120:168-73.

Prinstein, M. J., \& Wang, S. S. (2005). False consensus and adolescent peer contagion: Examining discrepancies between perceptions and actual reported levels of friends' deviant and health risk behaviors. Journal of Abnormal Pychology, 33, 293-306.

Rosser, R., Stevens, S., \& Ruiz, B. (2005). Cognitive Markers Of Adolescent Risk Taking: A Correlate Of Drug Abuse In At-Risk Individuals. Prison Journal, 85(1), 83-96.

Rozmi, I., Azri, N. A., Fauziah, I., \& Salina, N. (2017). Pengaruh Faktor Individu, Keluarga dan Persekitaran Sosial Terhadap Tingkah Laku Penyalahgunaan Bahan dalam Kalangan Remaja. Akademika, 87(1), 7-16. 
Salud, S. D. (2002). National Survey of Addictions: Alcohol, tobacco and drugs. Retrieved from www.ssa.gob.mx.Mexico.

Seth, R., Kotwal, A., \& Ganguly, K. K. (2005). Street and Working Children in Delhi, India, Misusing Toluene: An Ethnographic Exploration. Substance Use and Misuse, 40, 16591679.

Shamblen, S. R., \& Miller, T. (2012). Inhalant initiation and the relationship of inhalant use to the use of other substances. J. Drug Education, 42(3) 327-346.

Smart, R. G. (1989). Inhalant use and abuse in Canada. In : Crider, R., and Rouse, B., eds. Epidemiology of Inhalant Abuse. An Update. Rockville, MD : National Institute on Drug Abuse.

Substance Abuse and Mental Health Services Administration. (2010). Results from the 2011 National Survey on Drug Use and Health: Summary of national findings (NSDUH Series H44, HHS Publication No. [SMA] 12-4713). Rockville, MD: Substance Abuse and Mental Health Services Administration.

Tiwari, P. (2006). Life on streets. Indian Journal of Pediatrics, 74(3), 283-286.

Turner, L. A., Powell, A. F., Rohling, L. J. \& Carson, J. (2009). Helping families initiative: interviewing with high risk students to a community, school, and district attorney partnership. Child and Adolescent Social Work Journal, 26 (3), 209-233.

Verma, R., Balhara, Y. P. S., \& Deshpande, S. N. (2011). Inhalant Abuse: a Study from a tertiary care de-addiction clinic. East Asian Arch Psychiatry, 21:157-63.

Wittig, M., Wright, J., \& Daminsky, D. (1997). Substance Use among street children in Honduras. substance use and misuse, 32, 805-827.

World Health Organization (WHO). (2016). Comprehensive Mental Health Action Plan 20132020. http://www.who.int/mental_health/action_plan_2013/en/.

Retrieved on: 15 March 2015

Wolfe, D. A. \& Mash, E. J. (2006). Behavioural and Emotional Disorders in Adolescents: Nature, Assessment and Treatment. New York, USA: The Guildford Press.

Wu, L. T., Pilowsky, D. J., \& Schlenger, W. E. (2004). Inhalant abuse and dependence among adolescents in the United States. Journal of the American Academy of Child Adolescent Psychiatry, 43, 1206-1214.

Yucel, M., Lubman, D. I., Solowij, N., \& Brewer, W. J. (2007). Understanding drug addiction: a neuropsychological perspective. Australian and New Zealand Journal of Psychiatry, 41(12), 957-968. 